\title{
FRASE KATA MEMERINTAHKAN DAN MEREKOMEMENDASIKAN DALAM PUTUSAN BAWASLU TERKAIT PELANGGARAN ADMINISTRATIF PEMILU
}

\author{
Fauzi Heri dan Retna Elyasari \\ KPU Kota Bandar Lampung \\ Jl. P. Sebesi No. 90, Sukarame, Bandar Lampung \\ fauzi.heri@gmail.com
}

\begin{abstract}
Election Supervisory Agency Regulation Number 8 Year 2018 concerning Settlement of Election Administrative Violations has become a guideline for the Election Supervisory Agency in accepting, examining, reviewing, and deciding allegations of Election Administrative Violations. However, there are inconsistencies in the verdict draft stated in Article 55 and Article 56 where there are phrases "ordered" and "recommend". The General Election Commission must follow up the verdict of the Election Supervisory Agency Election. The verdict of the Election Supervisory Agency contains the phrase "ordered" will not be interpreted otherwise. While the phrase "recommend" can be interpreted differently considering the word recommendation can be interpreted as a suggestion or input. This study is a normative legal research with a qualitative approach. Primary and secondary data were collected through interviews and legislation, general election books whereas the definitions of research variables obtained from dictionaries, encyclopedias and internet media. The results of this study indicates that the phrase "recommend" can be interpreted differently, therefore it has the potential for wrong execution.
\end{abstract}

Keywords: ordered, recommend, verdict of the election supervisory agency, election administrative violation 


\begin{abstract}
Abstrak
Peraturan Badan Pengawas Pemilu Nomor 8 Tahun 2018 tentang Penyelesaian Pelanggaran Administratif Pemilu menjadi pedoman Badan Pengawas Pemilu dalam menerima, memeriksa, mengkaji, dan memutus dugaan Pelanggaran Administratif Pemilu. Namun terdapat inkonsistensi dalam draft amar putusan yang diatur dalam Pasal 55 dan Pasal 56 dimana terdapat frase kata "memerintahkan" dan frase kata "merekomendasikan". Komisi Pemilihan Umum wajib menindaklanjuti putusan Badan Pengawas Pemilu tersebut. Putusan yang memuat frase kata "memerintahkan" tidak akan ditafsirkan lain. Sedangkan frase kata "merekomendasikan" dapat ditafsirkan lain mengingat kata rekomendasi dapat diartikan sebagai saran atau masukan. Jenis penelitian yang digunakan adalah penelitian hukum normatif dengan pendekatan kualitatif. Penulis mengumpulkan data primer dan data sekunder berupa pengumpulan wawancara dan dari peraturan perundang-undangan, buku-buku kepemiluan dan definisi terhadap variabel penelitian yang penulis dapatkan dari kamus, ensiklopedia dan media internet. Hasil penelitian menunjukkan bahwa kata rekomendasi dalam amar Putusan Bawaslu dapat ditafsirkan lain sehingga berpotensi salah eksekusi.
\end{abstract}

Kata kunci: memerintahkan, merekomendasikan, putusan badan pengawas pemilu, pelanggaran administratif pemilu

\section{Pendahuluan}

Undang-Undang Nomor 7 Tahun 2017 tentang Pemilihan Umum memberikan kewenangan baru kepada Badan Pengawas Pemilu (Bawaslu) berupa kewenangan membuat putusan dalam penanganan pelanggaran administratif Pemilu.

Peraturan Bawaslu Nomor 8 Tahun 2018 tentang Penyelesaian Pelanggaran Administratif Pemilu mendefinisikan pelanggaran administratif dalam Pemilu terbagi menjadi dua, yaitu:

1) Pelanggaran Administratif Pemilu:

Perbuatan atau tindakan yang melanggar tata cara, prosedur, atau mekanisme yang berkaitan dengan administrasi pelaksanaan Pemilu dalam setiap tahapan penyelenggaraan Pemilu.

2) Pelanggaran Administratif Pemilu yang terjadi secara Terstruktur, Sistematis, dan Masif atau disebut Pelanggaran Pemilu TSM:

Perbuatan atau tindakan yang melanggar tata cara, prosedur, atau mekanisme yang berkaitan dengan administrasi pelaksanaan Pemilu dalam setiap tahapan penyelenggaraan Pemilu, dan/ atau Pasangan Calon,calon anggota DPR, DPD, DRRD Provinsi, DPRD Kabupaten/Kota, menjanjikan dan/ atau memberikan uang atau materi lainnya untuk mempengaruhi 
penyelenggara Pemilu dan/atau

Pemilih yang terjadi secara tersruktur, sistematis, dan masif.

Sebagaimana diatur dalam Pasal 461 ayat (1) Undang-Undang Nomor 7 Tahun 2017, Bawaslu, Bawaslu Provinsi, Bawaslu Kabupaten/Kota menerima, memeriksa, mengkaji, dan memutus pelanggaran administratif Pemilu.

Bawaslu selanjutnya membentuk Majelis Pemeriksa dalam penyelesaian pelanggaran administratif Pemilu dan pelanggaran Pemilu TSM. Majelis Pemeriksa dipimpin oleh Ketua yang berasal dari Ketua Bawaslu di setiap tingkatan yang pembentukannya dilakukan melalui Rapat Pleno. Majelis Pemeriksa paling sedikit berjumlah 3 (tiga) orang yang berasal dari Ketua dan Anggota Bawaslu.

Objek pelanggaran administratif Pemilu berupa perbuatan atau tindakan yang melanggar tata cara, prosedur, atau mekanisme yang berkaitan dengan administrasi pelaksanaan Pemilu dalam setiap tahapan penyelenggaraan Pemilu. Sedangkan objek pelanggaran Pemilu TSM terdiri atas:

a) Perbuatan atau tindakan yang melanggar tata cara, prosedur, atau mekanisme yang berkaitan dengan administrasi pelaksanaan Pemilu dalam setiap tahapan Penyelenggaraan Pemilu yang terjadi secara terstruktur, sistematis, dan masif; dan/atau

b) Perbuatan atau tindakan menjanjikan dan/atau memberikan uang atau materi lainnya untuk mempengaruhi penyelenggara Pemilu dan/ atau Pemilih yang terjadi secara terstruktur, sistematis, dan masif. Pelanggaran administratif Pemilu berasal dari temuan atau laporan Pelanggaran Pemilu dimana Pihak Pelapornya adalah WNI yang telah memiliki hak pilih, peserta Pemilu dan pemantau Pemilu.

Pihak Terlapor dalam dugaan pelanggaran administratif Pemilu adalah calon anggota DPR/ DPD/ DPRD Provinsi/ DPRD Kabupaten/Kota, Pasangan Calon, tim kampanye, dan/atau Penyelengara Pemilu. Sedangkan Pihak Terlapor dugaan pelanggaran Pemilu TSM adalah calon anggota DPR/ DPD/ DPRD Provinsi/ DPRD Kabupaten/Kota, dan/atau Pasangan Calon.

Temuan dan laporan dugaan pelanggaran administratif Pemilu dan pelanggaran Pemilu TSM harus memenuhi syarat formil dan syarat materiil yang diatur dalam Peraturan Bawaslu Nomor 8 Tahun 2018.

Majelis Pemeriksa memutus pelanggaran administratif Pemilu dan pelanggaran Pemilu TSM berdasarkan paling sedikit 2 (dua) alat bukti yang sah. Alat bukti tersebut berupa keterangan saksi, surat atau tulisan, petunjuk, dokumen elektronik, keterangan Pelapor atau keterangan terlapor dalam sidang pemeriksaan, dan/atau keterangan ahli.

Sanksi terhadap terlapor/pelaku pelanggaran administratif Pemilu adalah:

a) Perbaikan administrasi terhadap tata cara, prosedur, atau mekanisme sesuai dengan ketentuan peraturan perundang-undangan;

b) Teguran tertulis;

c) Tidak diikutkan pada tahapan tertentu dalam penyelenggaraan Pemilu; dan/atau

d) Sanksi administratif lainnya sesuai dengan ketentuan dalam undangundang mengenai Pemilu. 
Sedangkan sanksi terhadap terlapor/ pelaku yang terbukti melakukan tindakan pelanggaran Pemilu TSM berupa pembatalan sebagai calon anggota DPR, DPD, DPRD Provinsi, DPRD Kabupaten/ Kota, atau Pasangan Calon.

Majelis pemeriksa melakukan pemeriksaan pendahuluan atas kelengkapan dan keabsahan dokumen dan membuat putusan pendahuluan. Putusan tersebut akan menentukan apakah dugaan pelanggaran administratif Pemilu dan pelanggaran Pemilu TSM dapat dilanjutkan ke tahap sidang atau tidak.

Selanjutnya dalam Pasal 55 dan Pasal 56 Peraturan Bawaslu Nomor 8 Tahun 2018 tentang Penyelesaian pelanggaran administratif Pemilu mengatur tentang amar putusan. Pasal 55 mengatur amar putusan terkait pelanggaran administratif Pemilu yang di dalamnya memuat frase kata "memerintahkan", sedangkan Pasal 56 mengatur tentang pelanggaran Pemilu TSM di dalamnya memuat frase kata "merekomendasikan".

Penulis melihat adanya inkonsistensi dalam draft amar putusan yang diatur dalam Pasal 55 dan Pasal 56 tersebut. Putusan Bawaslu yang memuat frase kata "memerintahkan" tidak akan ditafsirkan lain karena dengan tegas memberi perintah.

Sedangkan frase kata "merekomendasikan" dapat ditafsirkan lain mengingat kata rekomendasi dapat diartikan sebagai saran atau masukan. Padahal sanksi atas pelanggaran administratif Pemilu TSM sangat berat yaitu berupa pembatalan sebagai calon.

Meskipun sifat putusan Bawaslu yang final dan mengikat bagi pelanggaran administratif Pemilu dikecualikan jika berkaitan dengan sanksi pembatalan calon
- Pihak Terlapor masih dapat melakukan upaya hukum ke Mahkamah Agung namun inkonsistensi amar putusan atas laporan pelanggaran administratif Pemilu dan pelanggaran Pemilu TSM itu menurut penulis sangat menarik untuk diteliti.

Untuk mengkonstruksi analisis terhadap persoalan di atas, maka penulis melakukan penelitian dengan judul "Frase Kata memerintahkan dan merekomemendasikan dalam putusan Bawaslu terkait Pelanggaran Administratif Pemilu".

\section{Metode Penelitian}

Penelitian ini menggunakan metode penelitian hukum normatif. Penelitian hukum normatif menurut Soerjono Soekanto (2006) adalah pendekatan yang dilakukan berdasarkan bahan baku utama, menelaah hal yang bersifat teoritis yang menyangkut asas-asas hukum, konsepsi hukum, pandangan dan doktrin-doktrin hukum, peraturan dan sistem hukum dengan menggunakan data sekunder, diantaranya asas, kaidah, norma dan aturan hukum yang terdapat dalam peraturan perundang-undangan dan peraturan lainnya, dengan mempelajari buku-buku, peraturan perundangundangan dan dokumen lain yang berhubungan erat dengan penelitian.

Penelitian ini dilakukan dengan mengumpulkan data sekunder untuk kemudian dilakukan kajian kepustakaan terhadap literatur dan bahan tertulis berupa peraturan perundang-undangan, putusan atas perkara yang diteliti, maupun bahan tulisan lainnya yang diperoleh penulis dari media dan internet. Data sekunder yang menjadi bahan baku utama penelitian ini adalah Peraturan Bawaslu Nomor 8 Tahun 2018 tentang 
Penyelesaian Pelanggaran Administratif Pemilu.

Data primer yang didapatkan penulis kemudian digunakan untuk menunjang hasil kajian berdasarkan data sekunder yang telah dianalisis terlebih dahulu. Data primer dalam penelitian ini diperoleh melalui wawancara, serta data yang diperoleh berdasarkan pengamatan di lapangan yang terkait dengan obyek penelitian.

Teknik pengumpulan data yang penulis gunakan dalam penelitian ini dilakukan dengan menggunakan 2 (dua) cara, yaitu:

\section{a) Studi Pustaka}

Studi pustaka dilakukan dengan tujuan untuk memperoleh bahan hukum sekunder dengan cara membaca, mencatat dan mengutip dari berbagai literatur, peraturan perundang-undangan, buku, surat kabar, media massa, internet dan bahan tertulis lainnya yang berhubungan dengan penelitian.

\section{b) Studi Lapangan}

Studi lapangan dalam penelitian ini dilakukan dengan cara melakukan wawancara. Informan dalam penelitian ini berjumlah 2 (dua) orang yaitu:

1. Iskardo P. Panggar, Anggota Bawaslu Provinsi Lampung.

2. Dedy Triyadi, Ketua Divisi Hukum KPU Kota Bandar Lampung

Pengolahan data dilakukan dengan cara validasi, pemberian kode, sistematisasi data untuk selanjutnya dilakukan analisis.

\section{Perspektif Teori}

Hukum menurut Hans Kelsen adalah ilmu normatif (science of norm). Komponen utama teori Kelsen, dikutip dari jurnal Atip Latipulhayat (2014) adalah teori tentang norma yang didefinisikan sebagai proposisi yang berhubungan dengan sesuatu yang harus terjadi atau sesuatu yang harus dilakukan (ought to happen). Namun sebaliknya norma bukan "ought to proposition" dalam pengertian bahwa norma tersebut mengharuskan orang untuk berprilaku dalam bingkai moral (in a moral sense).

Ilmu hukum (legal science) menurut Kelsen bukan untuk memberikan penilaian terhadap norma atas dasar parameter moral, tetapi untuk menafsirkan secara objektif sebagai bagian dari sistem hukum. Dengan kata lain, norma bukan hanya dipahami sebagai rumusan yang melarang atau memerintahkan seseorang untuk melakukan suatu perbuatan dengan cara tertentu, tetapi harus dikemas dalam rumusan hukum (legal statement) mengenai apa yang akan terjadi apabila seseorang melakukan perbuatan tersebut. Dalam kaitannya dengan hal tersebut, Hans Kelsen menemukan sebuah teori Piramida atau dikenal dengan sebutan teori Stufenbau. Teori Piramida didefinisikan sebagai sebuah teori mengenai sistem hukum.

Teori tersebut menurut Hans Kelsen (2010) menyatakan bahwa sistem hukum merupakan sistem anak tangga dengan kaidah berjenjang dimana norma hukum yang paling rendah harus berpegangan pada norma hukum yang lebih tinggi, dan kaidah hukum yang tertinggi (seperti konstitusi) harus berpegangan pada norma hukum yang paling mendasar (grundnorm).

Selanjutnya Hans Nawiasky salah seorang murid Hans Kelsen mengembangkan teori tersebut sebagai theorie von stufenufbau der 
rechtsordnung. Adapun susunan norma tersebut menurut teori sebagaimana dikutip dari Jimly Ashiddiqie dan M. Ali Safa'at (2006) adalah:

1) Norma fundamental negara (Staatsfundamentalnorm);

2) Aturan dasar negara (staatsgrundgesetz);

3) Undang-undang formal (formell gesetz); dan

4) Peraturan pelaksanaan dan peraturan otonom (verordnung en autonome satzung).

Seorang ahli Hukum Tata Negara A. Hamid S. Attamimi (1990) mengintegrasikan teori Kelsen dengan teori Hans Nawiaky dan menerapkannya pada struktur tata hukum di Indonesia. Attamimi menunjukkan struktur hierarki tata hukum Indonesia dengan menggunakan teori Nawiasky. Dengan berdasarkan teori tersebut, struktur tata hukum Indonesia dapat disusun sebagai berikut:

1) Staats fundamental norm: Pancasila (Pembukaan Undang-Undang Dasar 1945).

2) Staats grundgesetz: Batang Tubuh Undang-Undang Dasar 1945, TAP MPR, dan Konvensi Ketatanegaraan.

3) Formell gesetz: Undang-Undang.

4) Verordnung en Autonome Satzung: Secara bertingkat mulai dari Peraturan Pemerintah hingga Keputusan Bupati atau Walikota.

Teori ini diadopsi dalam tata hukum Indonesia sebagaimana yang diatur dalam Undang-Undang No. 12 Tahun 2011 tentang Pembentukan Peraturan Perundang-Undangan pada pasal 7 ayat 1 disebutkan bahwa jenis dan tata urutan Peraturan Perundang-undangan terdiri atas:
1) Undang-Undang Dasar Negara Republik IndonesiaTahun 1945;

2) Ketetapan Majelis Permusyawaratan Rakyat;

3) Undang-Undang/Peraturan Pemerintah Pengganti UndangUndang;

4) Peraturan Pemerintah;

5) Peraturan Presiden;

6) Peraturan Daerah Provinsi; dan

7) Peraturan Daerah Kabupaten/Kota.

Selanjutnya Pasal 8 ayat (1) UndangUndang No. 12 Tahun 2011 tentang Pembentukan Peraturan PerundangUndangan mengatur bahwa jenis Peraturan Perundang-undangan selain sebagaimana dimaksud dalam Pasal 7 ayat (1) di atas mencakup peraturan yang ditetapkan oleh Majelis Permusyawaratan Rakyat, Dewan Perwakilan Rakyat, Dewan Perwakilan Daerah, Mahkamah Agung, Mahkamah Konstitusi, Badan Pemeriksa Keuangan, Komisi Yudisial, Bank Indonesia, Menteri, badan, lembaga, atau komisi yang setingkat yang dibentuk dengan Undang-Undang atau Pemerintah atas perintah Undang-Undang, DPRD Provinsi, Gubernur, DPRD Kabupaten/Kota, Bupati/ Walikota, Kepala Desa atau yang setingkat. Peraturan perundang-undangan tersebut diakui keberadaannya dan mempunyai kekuatan hukum mengikat sepanjang diperintahkan oleh peraturan perundangundangan yang lebih tinggi atau dibentuk berdasarkan kewenangan.

Undang-Undang Nomor 7 Tahun 2017 tentang Pemilihan Umum memberikan kewenangan kepada Bawaslu untuk membuat peraturan teknis yang menjadi aturan pelaksana terhadap Undang-Undang sebagaimana dijelaskan dalam Undang-Undang No. 12 Tahun 
2011 tentang Pembentukan Peraturan Perundang-Undangan.

Selanjutnya berdasarkan perspektif teori kewenangan menurut Bagir Manan (2000) istilah wewenang dengan kekuasaan macht itu berbeda. Kekuasaan menurutnya hanya digambarkan hak untuk berbuat atau tidak berbuat. Sedangkan wewenang memiliki pengertian yang lebih luas meliputi hak dan kewajiban (rechten en plichten).

Philipus M. Hadjon (1998) membagi cara memperoleh wewenang atas dua cara, yaitu:

1) atribusi; dan

2) delegasi dan kadang-kadang juga mandat.

Atribusi merupakan wewenang untuk membuat keputusan (besluit) yang langsung bersumber kepada undangundang dalam arti materiil. Atribusi juga dikatakan sebagai suatu cara normal untuk memperoleh wewenang pemerintahan. Sehingga tampak jelas bahwa kewenangan yang didapat melalui atribusi oleh organ pemerintah adalah kewenangan asli, karena kewenangan itu diperoleh langsung dari peraturan perundang-undangan (utamanya UUD 1945). Dengan kata lain, atribusi berarti timbulnya kewenangan baru yang sebelumnya kewenangan itu, tidak dimiliki oleh organ pemerintah yang bersangkutan.

Delegasi diartikan sebagai penyerahan wewenang untuk membuat besluit oleh pejabat pemerintahan (pejabat Tata Usaha Negara) kepada pihak lain. Definisi frase kata penyerahan itu adalah adanya perpindahan tanggung jawab dan yang memberi delegasi (delegans) kepada yang menerima delegasi (delegetaris).
Pasal 461 ayat (1) Undang-Undang Nomor 7 Tahun 2017 tentang Pemilihan Umum mengatur bahwa Bawaslu, Bawaslu Provinsi, Bawaslu Kabupaten/ Kota menerima, memeriksa, mengkaji dan memutus pelanggaran administratif Pemilu. Frase kata "memutus" diterjemahkan sebagai kewenangan baru Bawaslu salah satunya untuk membuat putusan atas pelanggaran administratif Pemilu.

Kewenangan membuat putusan itu dapat diterjemahkan bahwa Bawaslu di setiap tingkatan menjalankan fungsi kehakiman. Hal itu dapat dilihat dalam Peraturan Bawaslu Nomor 8 Tahun 2018 tentang Penyelesaian Pelanggaran Administratif dimana Bawaslu melalui rapat pleno membentuk Majelis Pemeriksa. Penamaan dengan menggunakan frase kata "Majelis" ini juga merujuk kepada penamaan Majelis Hakim dalam lembaga peradilan.

Oleh karena itu, sesuai dengan penamaannya, maka "putusan" Bawaslu itu juga dipersyaratkan untuk diputuskan di dalam sidang pemeriksaan terbuka. Hal itu juga berlaku sama dengan putusan hakim yang diputuskan dalam suatu sidang terbuka.

Putusan terdefinisi sebagai produk hukum yang menimbulkan akibat hukum yang diputuskan oleh Hakim di dalam persidangan. Putusan Hakim merupakan suatu tindakan akhir yang dilakukan oleh Hakim di dalam persidangan. Putusannya akan menentukan terbukti bersalah atau tidak bersalah bagi si terlapor. Oleh karena itu, putusan Hakim dapat didefinisikan sebagai pernyataan dari hakim dalam memutuskan suatu perkara di dalam persidangan dan memiliki kekuatan hukum tetap. 
Berdasarkan landasan teoritik dan praktik, maka putusan Hakim itu merupakan:

"Putusan yang diucapkan oleh hakim karena jabatannya dalam persidangan perkara pidana yang terbuka untuk umum setelah melalui proses dan prosedural hukum acara pidana pada umumnya berisikan amar pemidanaan atau bebas atau pelepasan dari segala tuntutan hukum dibuat dalam bentuk tertulis dengan tujuan menyelesaikan perkara. (Lilik Mulyadi, 2007:127)

Setiap putusan hakim harus berisi penetapan-penetapan. Putusan hakim selain harus menyatakan seseorang terbukti bersalah atau tidak terbukti bersalah, juga harus memerintahkan kepada lembaga yang memiliki hak eksekusi atas putusan tersebut untuk menindaklanjuti putusan hakim.

Putusan hakim bersifat memaksa (dwingend), artinya jika ada pihak yang tidak mematuhinya hakim dapat memerintahkan pihak yang bersangkutan supaya mematuhinya dengan kesadaran sendiri. Putusan hakim menimbulkan akibat hukum bagi pihak-pihak yang terlibat.

Menurut R. Soeroso (2011) akibat hukum dapat berwujud:

- Lahirnya, berubahnya, atau lenyapnya suatu keadaan hukum.

- Lahirnya, berubahnya atau lenyapnya suatu hubungan hukum antara dua atau lebih subyek hukum, dimana hak dan kewajiban pihak yang satu berhadapan dengan hak dan kewajiban pihak yang lain.

- Lahirnya sanksi apabila dilakukan tindakan yang melawan hukum.

\section{Pembahasan}

Peraturan Bawaslu Nomor 8 Tahun 2018 tentang Penyelesaian Pelanggaran Administratif Pemilu berfungsi sebagai aturan teknis tentang tata cara penyelesaian pelanggaran administratif Pemilu. Sebagaimana teori Stufenbau, maka aturan teknis tersebut tidak boleh bertentangan dengan aturan di atasnya yakni Undang-Undang Nomor 7 Tahun 2017 tentang Pemilihan Umum.

Undang-Undang Nomor 7 Tahun 2017 Pasal 461 mengamanatkan:

1) Bawaslu, Bawaslu Provinsi dan Bawaslu Kabupaten/Kota menerima, memeriksa, mengkaji dan "memutus" pelanggaran administratif Pemilu.

2) Panwaslu Kecamatan menerima, memeriksa, mengkaji dan membuat rekomendasi atas hasil kajiannya mengenai pelanggaran administratif Pemilu kepada pengawas Pemilu secara berjenjang.

3) Pemeriksaan oleh Bawaslu, Bawaslu Provinsi, Bawaslu Kabupaten/Kota harus dilakukan secara terbuka.

4) Dalam hal diperlukan sesuai kebutuhan tindak lanjut penanganan pelanggaran Pemilu, Bawaslu, Bawaslu Provinsi, Bawaslu Kabupaten/Kota dapat melakukan investigasi.

5) Bawaslu, Bawaslu Provinsi, Bawaslu Kabupaten/Kota wajib memutus penyelesaian pelanggaran administratif Pemilu paling lama 14 (empat belas) hari kerja setelah temuan dan laporan diterima dan diregistrasi.

6) "Putusan" Bawaslu, Bawaslu Provinsi, Bawaslu Kabupaten/Kota untuk penyelesaian pelanggaran administratif Pemilu berupa: 
a) Perbaikan administrasi terhadap tata cara, prosedur, atau mekanisme sesuai dengan ketentuan peraturan perundangundangan;

b) Teguran tertulis;

c) Tidak diikutkan pada tahapan tertentu dalam Penyelenggaraan Pemilu; dan

d) Sanksi administratif lainnya sesuai dengan ketentuan dalam Undang-Undang ini.

Ketentuan di atas menyatakan dengan tegas bahwa Bawaslu di setiap tingkatan setelah menerima, memeriksa dan mengkaji, selanjutnya berhak "memutus" pelanggaran administratif Pemilu. Sedangkan Panwaslu Kecamatan setelah menerima, memeriksa dan mengkaji, selanjutnya hanya berhak membuat "rekomendasi" atas pelanggaran administratif Pemilu. Hal itu termuat dalam ayat (1) dan (2). Dengan kata lain ketentuan dalam aturan tersebut menyiratkan makna bahwa Bawaslu diberi kewenangan "memutus" yang diterjemahkan membuat "putusan" dan Panwaslu Kecamatan hanya diberi kewenangan sampai tahapan "mengkaji" yang selanjutnya produknya adalah "rekomendasi".

Selanjutnya dijelaskan bahwa dalam penyelesaian pelanggaran administratif Pemilu, Bawaslu di setiap tingkatan membuat "putusan" sebagaimana diatur dalam ayat (6). Artinya untuk penyelesaian pelanggaran administratif Pemilu, penyelesaiannya dengan cara membuat "putusan" yang kemudian diterjemahkan dilakukan dalam sidang terbuka dilakukan oleh Majelis Pemeriksa. Namun berbeda halnya dengan penyelesaian pelanggaran administratif Pemilu TSM, Bawaslu di setiap tingkatan diminta untuk "merekomendasikan" pembatalan calon yang terbukti melakukan pelanggaran administratif Pemilu TSM kepada KPU.

\subsection{Mekanisme Penyelesaian}

Peraturan Bawaslu Nomor 8 Tahun 2018 tentang Penyelesaian Pelanggaran Administratif Pemilu menerjemahkan ketentuan Pasal 461 Undang-Undang Nomor 7 Tahun 2017 tentang Pemilihan Umum dengan membuat tata cara penyelesaian pelanggaran administratif Pemilu yaitu dengan cara membentuk Majelis Pemeriksa. Pembentukan Majelis Pemeriksa ini mirip sekali dengan tata cara penyelesaian sengketa Pemilu melalui adjudikasi. Di mana penyelesaian sengketa proses Pemilu dilakukan dengan cara pembentukan Majelis Adjudikasi setelah proses mediasi gagal dilaksanakan.

Penanganan penyelesaian pelanggaran administratif Pemilu dan sengketa proses Pemilu dengan melakukan pembentukan Majelis Pemeriksa dan Majelis Adjudikasi tersebut menempatkan Bawaslu di setiap tingkatan menjalankan kekuasaan kehakiman. Hal itu ditandai dengan penyebutan "Majelis" yang sebelumnya dikenal sebagai istilah yang berlaku umum di pengadilan.

Oleh karena itu, frase kata "memutus" yang dimuat dalam Pasal 461 ayat (1) dan frase kata "putusan" yang dimuat dalam Pasal 461 ayat (6) Undang-Undang Nomor 7 Tahun 2017 tentang Pemilihan Umum, terdefinisi secara tepat oleh Peraturan Bawaslu Nomor 8 Tahun 2018 tentang Penyelesaian Pelanggaran Administratif Pemilu.

Selanjutnya di dalam Pasal 55 Peraturan Bawaslu Nomor 8 Tahun 2018 memuat ketentuan: 
(1) Dalam hal putusan Bawaslu/Bawaslu Provinsi/Bawaslu Kabupaten/Kota menyatakan laporan Pelanggaran Administratif Pemilu terbukti, amar putusan berbunyi,“MEMUTUSKAN", serta:

a. menyatakan terlapor, terbukti secara sah dan meyakinkan melakukan Pelanggaran Administratif Pemilu;

b. memerintahkan kepada KPU, KPU Provinsi, atau KPU Kabupaten/ Kota untuk melakukan perbaikan administrasi terhadap tata cara, prosedur, atau mekanisme pada tahapan Pemilu sesuai dengan ketentuan peraturan perundangundangan;

c. memberikan teguran tertulis kepada terlapor;

d. memerintahkan kepada KPU, KPU Provinsi, atau KPU Kabupaten/ Kota agar terlapor untuk tidak diikutkan pada tahapan Pemilu dalam penyelenggaraan Pemilu; dan/atau

e. memberikan sanksi administratif lainnya kepada terlapor sesuai dengan ketentuan undangundang mengenai Pemilu.

(2) Putusan Bawaslu, Bawaslu Provinsi, atau Bawaslu Kabupaten/ Kota menyatakan laporan tidak terbukti, amar putusan berbunyi, "MEMUTUSKAN", serta menyatakan terlapor tidak terbukti secara sah dan meyakinkan melakukan perbuatan melanggar tata cara, prosedur, atau mekanisme pada tahapan Pemilu sesuai dengan ketentuan peraturan perundang-undangan.

Draft amar putusan di atas dengan tegas memuat frase kata "memerintahkan" kepada KPU, KPU Provinsi, atau KPU Kabupaten/Kota. Frase kata "memerintahkan" tersebut sebagai penerjemahan dari kewenangan Bawaslu di setiap tingkatan dalam menyelesaikan pelanggaran administratif Pemilu yaitu menerima, memeriksa, mengkaji lalu "memutuskan" lewat putusan yang berisi frase kata "memerintahkan".

Sementara itu, pelanggaran administrasi Pemilu TSM penyelesaiannya diatur agak berbeda dengan pelanggaran administratif Pemilu biasa. Pasal 286 Undang-Undang Nomor 7 Tahun 2017 tentang Pemilihan Umum memuat:

(1) Pasangan Calon, calon anggota DPR, DPD, DPRD provinsi, DPRD kabupatenjkota, pelaksana kampanye, dan/atau tim kampanye dilarang menjanjikan dan/atau memberikan uang atau materi lainnya untuk memengaruhi Penyelenggara Pemilu dan/atau Pemilih.

(2) Pasangan Calon serta calon anggota DPR, DPD, DPRD provinsi, dan DPRD kabupaten/kota yang terbukti melakukan pelanggaran sebagaimana dimaksud pada ayat (1) berdasarkan rekomendasi Bawaslu dapat dikenai sanksi administratif pembatalan sebagai Pasangan Calon serta calon anggota DPR, DPD, DPRD provinsi, dan DPRD kabupaten/kota oleh KPU.

(3) Pelanggaran sebagaimana dimaksud pada ayat (2) merupakan pelanggaran yang terjadi secara terstruktur, sistematis, dan masif.

(4) Pemberian sanksi terhadap pelanggaran sebagaimana dimaksud pada ayat (2) tidak menggugurkan sanksi pidana.

Berdasarkan ketentuan di atas, maka Bawaslu hanya membuat rekomendasi 
berupa sanksi administratif pembatalan sebagai Pasangan Calon serta calon anggota DPR, DPD, DPRD provinsi, dan DPRD kabupaten/kota kepada KPU jika pelanggaran Pemilu TSM dinyatakan terbukti.

Namun selanjutnya Pasal 463 Undang-Undang Nomor 7 Tahun 2017 mengatur:

(1) Dalam hal terjadi pelanggaran administratif Pemilu sebagaimana dimaksud dalam Pasal 460 yang terjadi secara terstruktur, sistematis, dan masif, Bawaslu menerima, memeriksa, dan merekomendasikan pelanggaran administratif Pemilu dalam waktu palinglama 14 (empat belas) hari kerja.

(2) Pemeriksaan sebagaimana dimaksud pada ayat (1) harus dilakukan secara terbuka dan sesuai dengan ketentuan peraturan perundang-undangan.

(3) KPU wajib menindaklanjuti putusan Bawaslu dengan menerbitkan keputusan KPU dalam waktu paling lambat 3 (tiga) hari kerja terhitung sejak diterbitkannya putusan Bawaslu.

(4) Keputusan KPU sebagaimana dimaksud pada ayat (3) dapat berupa sanksi administratif pembatalan calon anggota DPR, DPD, DPRD provinsi, DPRD kabupaten/kota, dan Pasangan Calon Presiden dan Wakil Presiden.

(5) Calon anggota DPR, DPD, DPRD provinsi, DPRD kabupaten/kota, dan Pasangan Calon yang dikenai sanksi administratif pembatalan sebagaimana dimaksud pada ayat (4) dapat mengajukan upaya hukum ke Mahkamah Agung dalam waktu paling lambat 3 (tiga) hari kerja terhitung sejak keputusan KPU ditetapkan.
(6) Mahkamah Agung memutus upaya hukum pelanggaran administratif Pemilu sebagaimana dimaksud pada ayat (5) dalam waktu paling lama 14 (empat belas) hari kerja terhitung sejak berkas perkara diterima oleh Mahkamah Agung.

(7) Dalam hal putusan Mahkamah Agung membatalkan keputusan KPU sebagaimana dimaksud pada ayat (5), KPU wajib menetapkan kembali sebagai calon anggota DPR, DPD, DPRD provinsi, DPRD kabupaten/ kota, dan Pasangan Calon Presiden dan Wakil Presiden.

(8) Putusan Mahkamah Agung bersifat final dan mengikat.

Hasil analisis terhadap ketentuan di atas dirumuskan sebagai berikut:

- Bawaslu menerima, memeriksa dan merekomendasikan pelanggaran administratif Pemilu TSM. Pembuat Undang-Undang menghilangkan frase kata "memutus" sebagaimana diatur dalam penyelesaian pelanggaran administratif Pemilu biasa.

- Pemeriksaan atas pelanggaran administratif Pemilu TSM dilakukan secara terbuka. Ketentuan ini diterjemahkan dalam peraturan Bawaslu dengan melakukan sidang terbuka yang dilakukan oleh Majelis Pemeriksa.

- KPU wajib menindaklanjuti putusan Bawaslu. Hal ini diterjemahkan Bawaslu bahwa penyelesaian pelanggaran administratif Pemilu TSM juga dilakukan dengan cara membuat "putusan" atau sama dengan penyelesaian pelanggaran administratif Pemilu biasa. Padahal dalam sebuah "amar putusan" tidak dikenal frase kata 
"merekomendasikan". Selanjutnya KPU wajib menindaklanjuti putusan Bawaslu tersebut.

- Keputusan KPU atas "putusan" Bawaslu "dapat" berupa sanksi administratif pembatalan calon. Frase kata "dapat" sebagaimana diterjemahkan dalam Kamus Besar Bahasa Indonesia memiliki makna harafiah sebagai: mampu; sanggup; bisa; boleh; mungkin.

Berdasarkan uraian di atas, penulis menilai telah terjadi inkonsistensi atas pemberian wewenang baru kepada Bawaslu dalam hal menyelesaikan pelanggaran administratif Pemilu TSM. Kewenangan Bawaslu itu dibatasi hanya menerima, memeriksa dan merekomendasikan. Sementara produk hukum atas kewenangan Bawaslu menerima, memeriksa dan merekomendasikan pelanggaran administratif Pemilu TSM itu di sisi lain diatur dalam bentuk putusan.

Akibatnya, Bawaslu membuat aturan teknis mengenai tata cara penyelesaian pelanggaran Pemilu TSM sebagaimana diatur dalam Pasal 286 dan Pasal 463 Undang-Undang Nomor 7 Tahun 2017 dengan mekanisme penyelesaian yang sama dengan tata cara penyelesaian pelanggaran administratif Pemilu. Hal itu dipertegas dengan memasukkan Pelanggaran Pemilu TSM sebagai bagian dari pelanggaran administratif Pemilu.

Pembedanya hanya terdapat dalam amar putusannya saja. Dimana Pasal 56 Peraturan Bawaslu Nomor 8 Tahun 2018 tentang Penyelesaian Pelanggaran Administratif Pemilu memuat aturan:

1) Dalam hal putusan Bawaslu menyatakan laporan Pelanggaran Administratif Pemilu TSM terbukti, amar putusan berbunyi, "MEMUTUSKAN", serta:

a. menyatakan terlapor, terbukti secara sah dan meyakinkan melakukan Pelanggaran Administratif Pemilu berupa perbuatan menjanjikan dan/atau memberikan uang atau materi lainnya untuk mempengaruhi penyelenggara Pemilu dan/ atau Pemilih yang terjadi secara Tersruktur, Sistematis, dan Masif;

b. "merekomendasikan" kepada KPU untuk membatalkan terlapor sebagai calon anggota DPR/DPD atau Pasangan Calon;

C. "merekomendasikan" kepada KPU untuk memerintahkan KPU Provinsi membatalkan terlapor sebagai calon anggota DPRD Provinsi; atau

d. "merekomendasikan" kepada KPU untuk memerintahkan KPU Kabupaten/Kota untuk membatalkan, terlapor sebagai calon anggota DPRD Kabupaten/ Kota.

2) Putusan Bawaslu menyatakan Pelanggaran Administratif Pemilu TSM tidak terbukti, amar putusan berbunyi, "MEMUTUSKAN", serta menyatakan terlapor calon anggota DPR/ DPD/ DPRD Provinsi/ DPRD Kabupaten/Kota/ Pasangan Calon tidak terbukti secara sah dan meyakinkan melakukan perbuatan menjanjikan dan/atau memberikan uang atau materi lainnya untuk mempengaruhi penyelenggara Pemilu dan/atau Pemilih yang terjadi secara tersruktur, sistematis, dan masif. 
Frase kata "merekomendasikan" yang dimuat dalam draft amar putusan sebagaimana disebutkan di atas, sudah tepat jika dikaji berdasarkan pendekatan stufenbau teori Hans Kelsen. Artinya norma yang terkandung dalam Pasal 286 ayat (2) Undang-Undang Nomor 7 Tahun 2017 tidak terlanggar oleh adanya frase kata "merekomendasikan".

$\mathrm{Namun,} f \mathrm{rase} k \mathrm{kta}$ "merekomendasikan" itu menimbulkan potensi salah tafsir dalam pelaksanaannya. KPU yang memiliki hak eksekusi atas putusan Bawaslu tersebut, akan mengkaji kembali apakah putusan Majelis Pemeriksa yang memuat frase kata "merekomendasikan" itu bisa ditindaklanjuti atau tidak.

Frase kata "rekomendasi" sendiri menurut kamus besar bahasa Indonesia, terdefinisi sebagai saran atau masukan. Artinya frase kata rekomendasi secara harafiah memiliki arti yang tidak mengikat sehingga dapat dikaji kembali apakah dapat dilaksanakan atau tidak.

Selanjutnya frase kata "merekomendasikan" tidak dikenal dalam setiap pengambilan putusan yang diputuskan melalui mekanisme persidangan terbuka. Dalam setiap amar putusan yang diterbitkan oleh hakim tidak dikenal kata "merekomendasikan" karena akan menimbulkan multi tafsir dan salah diterjemahkan.

Padahal jika merujuk kepada putusan Majelis Hakim di persidangan, maka Putusan hakim bersifat memaksa (dwingend), artinya jika ada pihak yang tidak mematuhinya hakim dapat memerintahkan pihak yang bersangkutan supaya mematuhinya dengan kesadaran sendiri. Selain itu setiap putusan hakim harus berisi penetapan-penetapan.
Putusan hakim selain harus menyatakan seseorang terbukti bersalah atau tidak terbukti bersalah, juga harus memerintahkan kepada lembaga yang memiliki hak eksekusi atas putusan tersebut untuk menindaklanjuti putusan hakim.

Terlebih putusan Majelis Pemeriksa yang diputuskan melalui mekanisme persidangan itu bersifat deklaratoir dan perlu dijalankan oleh lembaga lain yang memiliki hak eksekusi yaitu KPU yang notabene adalah lembaga penyelenggara Pemilu yang memiliki kedudukan sejajar dengan Bawaslu sebagai pembuat putusan.

Berdasarkan uraian di atas, maka penulis berpendapat bahwa meski tidak ada pertentangan norma antara Pasal 286 ayat (2) Undang-Undang Nomor 7 Tahun 2017 tentang Pemilihan Umum dengan pasal 56 ayat (1) huruf b, c, dan d Peraturan Bawaslu Nomor 8 Tahun 2018 tentang Penyelesaian Pelanggaran Administratif Pemilu, namun penggunaan frase kata "merekomendasikan" dalam sebuah produk putusan, tidaklah tepat karena tidak mengandung sifat memaksa (dwingend) sebagaimana putusan hakim dan berpotensi menimbulkan multi tafsir dalam pelaksanaannya.

Hal itu mempertegas bahwa dalam menjalankan kewenangannya membuat peraturan, Bawaslu hanya an sich memperhatikan agar norma dari aturan yang dibuatnya tidak bertentangan dengan Undang-Undang Nomor 7 Tahun 2017 tentang Pemilu saja. Namun Bawaslu tidak melakukan kajian mendalam dengan melakukan pengkajian dari seluruh aspek baik landasan teori, filosofis, dan kebiasaan yang selama ini dikenal dalam praktek hukum di lembaga peradilan. 
Kondisi tersebut sangat jauh berbeda dengan apa yang dilakukan oleh KPU dalam menerjemahkan Undang-Undang Nomor 7 Tahun 2017 tentang Pemilu. Peraturan KPU justru dirancang untuk kemudian ditetapkan dengan cara lebih progresif. Peraturan KPU justru lebih berani mengisi celah hukum yang ditimbulkan oleh norma Undang-Undang Pemilu. KPU lebih progresif merancang aturan dengan berani terbuka meminta saran dan masukan dari masyarakat meskipun terkadang tindakan itu justru dinilai melampaui kewenangannya dalam membuat sebuah regulasi.

Pada perhelatan Pemilu Tahun 2019, KPU membuat aturan larangan mencalonkan diri bagi mantan terpidana korupsi, bandar narkoba dan kejahatan seksual terhadap anak. Aturan ini langsung menjadi kontroversi karena sejumlah tokoh partai politik yang pernah menjadi terpidana kasus korupsi terjegal pencalonannya. Meskipun akhirnya Mahkamah Agung mengabulkan permohonan uji materiil atas aturan tersebut, namun dalam pendapat hukumnya KPU menyatakan bahwa dalam membuat aturan tersebut KPU tidak saja berpedoman kepada Undang-Undang Pemilu tetapi juga berpedoman kepada nilai-nilai etika yang berlaku dalam masyarakat.

Aturan kontroversi lainnya yang saat ini tengah menjadi perbincangan di masyarakat adalah KPU pada tanggal 2 Oktober 2019 melakukan uji publik terhadap revisi Peraturan KPU Nomor 3 Tahun 2017 tentang Pencalonan dalam Pemilihan Kepala Daerah dan Wakil Kepala Daerah. KPU kembali memasukan larangan mencalonkan diri sebagai Kepala Daerah dan Wakil Kepala Daerah bagi orang yang pernah melakukan perbuatan tercela seperti judi, mabuk, pemakai atau pengedar narkoba, berzina dan/ atau melanggar perbuatan melanggar kesusilaan lainnya.

Hal tersebut mengakibatkan adanya perbedaan antara produk regulasi yang dibuat oleh Bawaslu dan KPU. Padahal kedua lembaga itu berkedudukan setara sebagai lembaga penyelenggara Pemilu. Peraturan Bawaslu terlihat lebih kaku dalam memegang norma yang terkandung dalam Undang-Undang Pemilu, sedangkan Peraturan KPU lebih bersifat progresif.

\subsection{Sanksi Pidana}

Hasil wawancara dengan informan, penulis menemukan fakta bahwa kata rekomendasi Bawaslu dalam Pemilu adalah sebuah keharusan yang berakibat hukum berupa pidana jika tidak dilaksanakan.

"Di Bawaslu itu lebih dikenal istilah merekomendasikan daripada memerintahkan. Frase kata rekomendasi itu otomatis mengikat KPU di setiap tingkatan untuk menindaklanjuti sesuai hasil kajian Bawaslu," ujar Iskardo P. Panggar, Anggota Bawaslu Provinsi Lampung.

Sementara informan lainnya menyatakan:

"Setelah membaca Pasal 55 dan Pasal 56 Perbawaslu Nomor 8 Tahun 2018, terlihat kesan jika itu menyangkut pelanggaran administratif Pemilu biasa yang sanksinya hanya ringan, Bawaslu tegas memuat kata memerintahkan dalam putusannya, tetapi giliran pelanggaran Pemilu TSM yang berkonsekuensi pembatalan calon, putusan Bawaslu berubah lunak menjadi merekomendasikan," ujar Dedy Triyadi, Ketua Divisi Hukum KPU Kota Bandar Lampung. (Wawancara, Senin 18/07/2019) 
Hasil analisis berdasarkan wawancara dengan informan di atas, frase kata "rekomendasi" dalam Pemilu telah mengalami perubahan makna dari arti sesungguhnya. Secara harafiah rekomendasi berarti saran atau masukan, tetapi dalam Pemilu berubah maknanya menjadi hal yang wajib dilakukan.

\section{Bukti Empiris}

5 (lima) Anggota KPU Kota Palembang divonis bersalah karena tidak menjalankan rekomendasi Bawaslu Kota Palembang untuk melaksanakan Pemungutan Suara Lanjutan pada Pemilu Tahun 2019 yang lalu.

Pengadilan Negeri Kelas IA Khusus Palembang selanjutnya menjatuhkan putusan enam bulan penjara dengan masa percobaan satu tahun dan denda sepuluh juta rupiah subsider satu bulan penjara, terhadap 5 (lima) anggota KPU Kota Palembang karena tidak menindaklanjuti rekomendasi Bawaslu. Sebelumnya dalam tuntutannya jaksa penuntut Ursula Dewi mengatakan, lima terdakwa terbukti secara sah dan meyakinkan bersama-sama melakukan perbuatan yang menyebabkan hak pilih orang lain hilang seperti yang tercantum dalam pasal 510 Undang-Undang Nomor 7 tahun 2017 tentang pemilihan umum juncto pasal 55 KUHP.

"Para terdakwa terbukti tidak secara cermat saat melakukan verifikasi yang menentukan dilaksanakannya pemungutan suara lanjutan [PSL] atau tidak yang menyebabkan hilangkan hak pilih warga negara. Fakta persidangan dari saksi perbuatan, mereka [komisioner KPU Palembang] terbukti sebagaimana yang didakwakan," ujar dia. (CNN Indonesia, 2019)
Uraian peristiwa di atas makin mempertegas kesimpulan penulis bahwa penggunaan frase kata "rekomendasi" diikuti oleh frase kata Bawaslu telah mengalami perubahan makna yang menjadi suatu keharusan untuk dijalankan atau ditindaklanjuti. Apabila rekomendasi Bawaslu ditolak, maka dapat berakibat pidana.

\section{Kesimpulan dan Saran}

Berdasarkan uraian di atas, penulis berkesimpulan bahwa telah terjadi inkonsistensi terhadap draft amar putusan Bawaslu terkait pelanggaran Pemilu TSM. Hal itu dapat menimbulkan tafsir terhadap tindak lanjut pelaksanaan rekomendasi Bawaslu oleh KPU. Oleh karena itu, Bawaslu disarankan untuk mengajukan revisi terhadap UndangUndang Nomor 7 Tahun 2017 tentang Pemilu agar mekanisme penyelesaian pelanggaran Pemilu TSM bisa memuat secara tegas aturan tentang kewenangan Bawaslu membuat putusan bukan sekedar rekomendasi. Atau, setidaknya Bawaslu merevisi Pasal 56 Peraturan Bawaslu Nomor 8 Tahun 2018 tentang Pelanggaran Administratif Pemilu dengan mengganti frase kata "merekomendasikan" menjadi "memerintahkan".

Pelanggaran Pemilu TSM yang berakibat hukum pembatalan sebagai calon tidak saja berlaku dalam Pemilu, tetapi juga telah lebih dulu diterapkan pada pelaksanaan Pemilihan Kepala Daerah. Beberapa catatan dalam pelaksanaan Pemilihan Kepala Daerah seperti dalam Pilgub Lampung, Bawaslu Provinsi yang diberi kewenangan untuk memutuskan pelanggaran Pemilihan TSM ditekan sedemikian rupa oleh massa pro dan kontra. Berdasarkan pengamatan 
dalam proses penyelesaian dugaan pelanggaran Pemilihan TSM dalam Pilgub Lampung itu, Majelis Pemeriksa dalam hal ini Bawaslu Provinsi Lampung menjadi pihak yang menjadi sasaran unjuk rasa masa pro dan kontra.

Menyusul hal tersebut, Pimpinan Bawaslu di daerah dikhawatirkan secara psikologis terpengaruh oleh tekanan masa pendukung sehingga tidak bisa memberikan keputusan yang seadiladilnya. Sebagai bentuk evaluasi terhadap kewenangan baru yang diberikan kepada Bawaslu dalam hal penyelesaian pelanggaran Pemilu/Pemilihan TSM itu, maka penulis juga menyarankan agar Bawaslu melakukan telaah untuk mengadobsi sistem juri sebagai bagian tak terpisahkan dalam tata cara penyelesaian pelanggaran Pemilu TSM di mana juri berperan membuat keputusan atau membuat temuan fakta yang kemudian diterapkan oleh Majelis Pemeriksa. Dengan mengadopsi sistem juri dalam peradilan pelanggaran Pemilu/Pemilihan TSM, maka tekanan masa pendukung calon baik pro dan kontra akan bisa diminimalisir sehingga putusan yang ditetapkan dapat merupakan putusan yang seadil-adilnya tanpa didasari ketakutan dan tekanan dari berbagai pihak. 


\section{DAFTAR PUSTAKA}

Ashiddiqie, Jimly \& Safaát, M. Ali. (2006). Teori Hans Kelsen tentang Hukum. Jakarta, Indonesia: Konpress.

Attamimi, A. Hamid S. (1990). Peranan Keputusan Presiden Republik Indonesia dalam Penyelenggaraan Negara. Jakarta, Indonesia: Fakultas Pascasarjana UI.

Hadjon, Philipus M. (1998). Tentang Wewenang Pemerintahan (Bestuurbevoegdheid). Jakarta, Indonesia: Pro Justitia Tahun XVI Nomor I.

Latifulhayat, Atip. (2014). Khazanah Hans Kelsen, hlm. 197-198, http://jurnal. unpad.ac.id/pjih/article/download/7056/3338.

Manan, Bagir. (2000). Wewenang Propinsi, Kabupaten dan Kota dalam Rangka Otonomi Daerah. Bandung, Indonesia: Fakultas Hukum Universitas Padjadjaran.

Mulyadi, Lilik. (2007). Kompilasi Hukum Pidana dalam Perspektif Teoritis dan Praktek Peradilan. Bandung, Indonesia: Mandar Maju.

Palembang. (2019, Juli 11). KPU Lima Komisioner Palembang dituntut 6 Bulan Penjara. CNN Indonesia. Diakses dari: https://www.cnnindonesia.com/ nasional/20190711184837-12-411392/lima-komisioner-kpu-palembang-dituntut6-bulan-penjara

Soekanto, Soerjono. (2006). Pengantar Penelitian Hukum. Jakarta, Indonesia: UI-Press. Soeroso, R. (2011). Pengantar Ilmu Hukum. Jakarta, Indonesia: Sinar Grafika. 